\title{
Correction to: Endogenous nutrients are concentrated in specific tissues in the Zea mays seedling
}

\section{T. C. Pesacreta ${ }^{1}$ (D) A. Acharya ${ }^{2} \cdot$ K. H. Hasenstein ${ }^{2}$}

Published online: 2 March 2021

(C) Springer-Verlag GmbH Austria, part of Springer Nature 2021

\section{Correction to: Protoplasma}

$$
\text { https://doi.org/10.1007/s00709-021-01606-4 }
$$

The acknowledgment text was omitted from the original version in error.

Acknowledgements The research was partially supported by NASA grant $80 \mathrm{NSSC} 17 \mathrm{~K} 0344$ to $\mathrm{KHH}$.

Publisher's note Springer Nature remains neutral with regard to jurisdictional claims in published maps and institutional affiliations.

The online version of the original article can be found at https://doi.org/ 10.1007/s00709-021-01606-4

$\triangle$ T. C. Pesacreta

tcp9769@louisiana.edu

A. Acharya

aniruddha1302@gmail.com

K. H. Hasenstein

karl.hasenstein@louisiana.edu

1 Microscopy Center, University of Louisiana Lafayette, PO Box 43602-3602, Lafayette, LA 70504, USA

2 Biology Department, University of Louisiana Lafayette, PO Box 43602-3602, Lafayette, LA 70504, USA 